\title{
TGF $\beta$ Presence During IgE-dependent Sensitization Primes Mast Cells for Higher VEGF Production After Fce RI Activation
}

\author{
Juan Pablo Benitez-Garrido ${ }^{1}$, Alfredo Ibarra-Sanchez ${ }^{1}$, Marina Macías Silva ${ }^{2}$, Rafael Villalobos Mo- \\ lina ${ }^{3}$, Jose Alejandro Padilla-Trejo ${ }^{4}$ and Claudia Gonzalez-Espinosa ${ }^{*}, 1$ \\ ${ }^{1}$ Pharmacobiology Department, Center for Research and Advanced Studies (Cinvestav), South Campus. ${ }^{2}$ Cellular \\ Physiology Institute, National Autonomous University of Mexico, ${ }^{3}$ Faculty of Superior Studies, Iztacala, National \\ Autonomous University of Mexico, ${ }^{4}$ Microbiology and Parasitology Department, Faculty of Medicine, National Autono- \\ mous University of Mexico.
}

\begin{abstract}
Binding of monomeric Immunoglobulin E (IgE) to the high affinity IgE receptor (FceRI) on mast cells induces a sensitization process which increases cell survival, augments membrane receptor expression and diminishes activation threshold. Although IgE-dependent sensitization is fundamental for allergic reactions, little is known about the influence of locally produced mediators on the outcome of a posterior allergen challenge. Since Transforming Growth Factor $\beta$ (TGF $\beta$ ) is an important immunomodulator present in most of the tissues where mast cells reside, we decided to analyze the consequences of TGF $\beta$ exposure during the sensitization step of mast cells on a posterior IgE-antigen stimulation. Bone Marrow-derived Mast Cells (BMMCs) were sensitized with IgE in the presence or absence of TGF $\beta$. Then, antigen was added and the secretion of the angiogenic cytokine Vascular Endothelial Growth Factor (VEGF) was determined. BMMCs sensitized with IgE+TGF $\beta$ showed an increased antigen-induced VEGF secretion compared to those sensitized with IgE alone. Sensitization with IgE+TGF $\beta$ did not modify membrane FceRI receptor expression neither altered antigen-induced degranulation of the cells. Although both IgE and IgE+TGF $\beta$ sensitized cells showed an increase in VEGF mRNA stabilization after antigen addition, VEGF mRNA half-life was longer in IgE+TGF $\beta$ sensitized cells. p38 MAPK inhibitor SB202196 blocked VEGF mRNA stabilization after antigen addition specially on IgE+TGF $\beta$ sensitized cells. These findings suggest that TGF $\beta$ presence during the sensitization phase of mast cells can induce modifications to the FceRI signal transduction system, provoking increased VEGF mRNA stabilization and protein secretion after IgE-antigen stimulation through a p38 MAPK-dependent mechanism.
\end{abstract}

Keywords: TGF $\beta$, Mast cell, IgE, VEGF, Sensitization.

\section{INTRODUCTION}

Mast cells are important players in anaphylaxis and immunoglobulin E (IgE)-associated allergic diseases such as atopic asthma, allergic rhinitis and atopic dermatitis [1]. Allergic individuals produce IgE antibodies that have specificity for the antigens to which the subjects are sensitive, and those antibodies are bound to the membrane of mast cells due its interaction with the high affinity $\operatorname{IgE}$ receptors (FceRI) [2]. In the absence of antigen, binding of monomeric $\mathrm{IgE}$ to FceRI receptors produce a sensitization process that allows mast cells to increase survival, augment FceRI receptor expression on the plasma membrane, and undergo degranulation at lower concentrations of antigen, releasing larger amounts of inflammatory mediators after IgE-antigen stimulation [3]. Long-lasting sensitization with monomeric $\operatorname{IgE}$ is a common condition in atopic individuals, where high concentrations of $\operatorname{IgE}$ in plasma have been proposed to induce increased mast cell numbers and promote responsiveness to very low amounts of antigen [4].

\footnotetext{
*Address correspondence to this author at the Pharmacobiology Department, CINVESTAV, South Campus, Calzada de los Tenorios \# 235, Col. Granjas Coapa, CP 14330, Mexico City, Mexico; Tel: (55) 5483 2875; Fax: (55) 5843 2863; E-mail: cgonzal@ cinvestav.mx
}

Once cell sensitization occurs, mast cells are ready to be activated by the antigen-mediated crosslinking of monomeric receptors. Activated FceRI receptor turns on a complex signaling cascade, which include activation of at least two different Src-family kinases (Lyn and Fyn), activation of Syk kinase, phosphorylation of different adapters (such as LAT and Gab2) and the formation of multimolecular aggregates that can connect the initial signal to intracellular calcium rise, MAP kinase activation, cytoskeletal movements and differential gene expression [5]. After FceRI crosslinking, mast cells are able to start the synthesis of multiple cytokine mRNAs that will be translated at different rates, allowing them to secrete a variety of interleukins, chemokines and angiogenic factors [1].

One of the more distinctive characteristics of the FceRI signal transduction system is the capacity of coupling to specific cellular effectors depending on the particular composition of the multimolecular complexes formed at the plasma membrane [6], this important feature suggest that, potentially, signaling could be modulated by the presence of different locally-produced mediators surrounding mast cells. Those cytokines, growth factors or neurotransmitters, acting on mast cells, could alter the availability of signaling mole- 
cules in different complexes, or produce positive/negative regulators of the FceRI signaling pathway [7].

TGF $\beta$ s are regulatory cytokines with pleiotropic effects on cell proliferation, differentiation, migration and survival, affecting multiple biological processes including development, fibrosis, wound healing, and immune responses [8]. There are three homologous TGF $\beta$ isoforms in mammals, TGF $\beta 1$, TGF $\beta 2$, and TGF $\beta 3$, encoded by different genes [9]. TGF $\beta 1$ is the predominant isoform expressed in the immune system, but all three isoforms have similar properties in vitro. It is locally produced in tissues where mast cells reside and is importantly synthesized in conditions of tissue remodeling and angiogenesis [10]. TGF $\beta 1$, normally referred solely as TGF $\beta$, is a profibrotic and immunomodulatory factor that, depending on the conditions, can act as a pro- or anti-inflammatory cytokine [8].

Vascular Endothelial Growth Factor, known alternatively as VEGF-A, is one of the most potent angiogenic cytokines described to date [11]. Murine VEGF is encoded by a single gene located on chromosome 17 and alternative splicing yields three predominant VEGF variants, including VEGF 120, 164 and 188 (corresponding to the human homologues 121,165 and 189, respectively). VEGF variants possess different bioavailabilities, due to differential affinities for heparin and for specific VEGF receptors. The shorter splice variants are soluble, while longer splice variants associate with extracellular matrix components, through its interaction with proteoglycans [11]. Mast cells are able to produce VEGF after FceRI activation [12, 13]. Human mast cell lines constitutively express $\mathrm{VEGF}_{121}, \mathrm{VEGF}_{165}, \mathrm{VEGF}_{189}$ transcripts and an important secretion is observed after mast cell stimulation, being VEGF present in secretory granules [12]. In murine peritoneal mast cells, an important antigeninduced increase on VEGF secretion was observed after a prolonged treatment with monomeric $\operatorname{IgE}$ [13].

Mast cell-secreted VEGF is involved in angiogenesis [14], the passage of IgE through the aortic endothelial cell monolayer [15] and also provokes changes on vascular permeability during the inflammation process [16]. Accordingly to the notion of a positive influence of mast cell-produced VEGF on angiogenesis, an increased number of mast cells have been observed in various tumors, including those in the lung [17], larynx [18], kidney [19], breast [20], and others [21]. High mast cell numbers positively correlates with increased microvessel density and has been considered as a sign of poor prognosis [22]. Despite of those findings, the main effect of mast cell-secreted VEGF seems to be related to enhanced microvascular permeability, causing leakage of macromolecules through the vesiculo-vacuolar organelle in endothelial cells [23]. Importantly, VEGF secretion after mast cell activation has been associated, together with $\mathrm{TGF} \beta$, to lung tissue remodeling observed in chronic asthma [24], a condition where the formation of new blood vessels has been reported.

In the present study, the effect of TGF $\beta$ during the IgEdependent sensitization of mast cells on a posterior FceRI receptor activation was analyzed. Particularly, we focused our attention on the analysis of VEGF secretion after FceRI crosslinking, since the molecular mechanisms involved in the release of angiogenic factors during allergic reactions have not been fully described.

\section{MATERIALS AND METHODS}

\section{Mice}

Four to eight weeks old 129S1/SvImJ mice (Jackson Laboratories Stock \# 002448) were sacrificed by $\mathrm{CO}_{2}$ inhalation and bone marrow was extracted from both tibias by injection of $3 \mathrm{ml}$ of complete BMMC media (see following sections) directly in the hollow of the bones. All the experimental procedures using mice were approved by our Institute Committee for the Experimental Use and Animal Care, (CICUAL, Protocol \# 383-07).

\section{Cell Culture}

Bone marrow derived mast cells (BMMCs) were differentiated seeding bone marrow in complete BMMC media containing RPMI 1640 culture media with L-glutamine (Sigma Cat. \# R4130), 20 ng/mL IL-3 (Preprotech Cat. \# 213-13), 25 mM HEPES buffer (Sigma, Cat. \#R4130), 10\% Fetal Bovine Serum (Gibco, BRL Cat. \# 261400779), 1X nonessential amino acids (100X stock, Biofluids, Cat. \# 332$100), 1 \mathrm{mM}$ sodium pyruvate (100 mM stock, Biofluids, Cat. \#33-100), $50 \mu \mathrm{M} \beta$-mercaptoethanol (Sigma, Cat. \# M6250) and $1 \mathrm{U} / \mathrm{mL}$ penicillin- $0.1 \mathrm{mg} / \mathrm{mL}$ streptomycin (stock $100 \mathrm{U} / \mathrm{ml}$ penicillin-10 mg/mL streptomycin GIBCO, Cat. \#10378-016). Cell cultures were grown at $37{ }^{\circ} \mathrm{C}$ in a humidified atmosphere with $5 \% \mathrm{CO}_{2}$, changing media once per week. Four weeks later, expression of FceRI receptor was assayed by flow cytometry, and only the cultures showing more than 95\% positive cells were used for the experiments. Human Vascular Endothelial Cells were purchased to BD Biosciences (HUVEC-2, Cat. \# 354115) and were maintained in MCDB-131 Complete Medium (Vec Technologies, Inc., Cat. \# MCDB-131 AB).

\section{Flow Cytometry}

Routine flow cytometry for detection of FceRI receptor in mature cultures was performed incubating $2 \times 10^{6}$ mast cells for one hour with $300 \mathrm{ng} / \mathrm{ml}$ of a monoclonal antidinitrophenol (DNP)-IgE (Sigma, Cat. \# D 8406), in staining buffer (PBS pH 7.4, 0.5\% bovine serum albumin, BSA, and $0.05 \%$ sodium azide). After this incubation, cells were washed once and incubated in the presence of a FITClabeled anti-IgE antibody (BD Biosciences Cat. \#553415). After $30 \mathrm{~min}$ incubation, cells were washed again and suspended in staining buffer before flow cytometry analysis, that was performed using a FACScan (Becton Dickinson). For changes on FceRI receptor expression after sensitization, the same FITC-labeled anti IgE ab was used.

\section{Apoptosis Detection Assay}

Mast cell apoptosis was evaluated using an Annexin V kit (BD Biosciences Cat. \# 556547) following the instructions provided by the manufacturer. Briefly, $2 \times 10^{6}$ mast cells were incubated overnight with $300 \mathrm{ng} / \mathrm{ml}$ of IgE (Sigma, Cat. \# D 8406), or IgE+100 pM TGF 3 (PeproTech, Cat. \#100-21R). Cells were washed with PBS and then AnnexinV-FITC and/or propidium iodide (PI) were added. Cells were incubated for $15 \mathrm{~min}$ at RT in the dark, washed once and suspended in the provided buffer prior to flow cytometry analysis. 


\section{Cell Sensitization and Stimulation}

Mature BMMCs were collected by centrifugation and suspended at $1 \times 10^{6}$ cells $/ \mathrm{mL}$ on fresh complete BMMC media warmed at $37^{\circ} \mathrm{C}$. For IgE-dependent sensitization, 300 $\mathrm{ng} / \mathrm{mL}$ of the monoclonal anti dinitrophenol (DNP)-IgE (Sigma, Cat. \# D 8406) were added to the media; in the case of IgE + TGF $\beta$ sensitization, $300 \mathrm{ng} / \mathrm{mL}$ IgE plus $100 \mathrm{pM}$ of recombinant TGF $\beta$ (Preprotech Cat. \# 100-21R, TGF- $\beta_{1}$ ) were added to the cells. Cells then were incubated for 18 hours at $37^{\circ} \mathrm{C}$. After this sensitization step, cells were collected and suspended in cell culture media or Tyrode's/BSA buffer (see following section) at $37^{\circ} \mathrm{C}$. For FceRI stimulation, different amounts of the synthetic antigen DNP coupled to Human Serum Albumin (DNP-HSA, Sigma Cat \# A-6661) were added. Depending on the parameter to be evaluated, reaction was stopped at optimal times and degranulation assays, RNA extractions or VEGF secretion assays were performed (see following sections).

\section{$\beta$-hexosaminidase Activity}

Degranulation was measured determining the amount of $\beta$-hexosaminidase activity in the supernatants of cells stimulated for 1 hour as it was described in the previous section. After sensitization, cells were collected and suspended in Tyrode's / BSA buffer $(130 \mathrm{mM} \mathrm{NaCl}, 5 \mathrm{mM} \mathrm{KCl}, 1 \mathrm{mM}$ $\mathrm{MgCl}_{2}, 1.4 \mathrm{mM} \mathrm{CaCl}_{2}, 5.6 \mathrm{mM}$ glucose, $20 \mathrm{mM}$ HEPES and $0.1 \% \mathrm{BSA}$ ) at $37^{\circ} \mathrm{C}$. Aliquots of $2 \times 10^{6} \mathrm{IgE}$-sensitized cells in $1 \mathrm{~mL}$ of Tyrode's buffer were then stimulated by the addition of different concentrations of DNP-HSA for one hour. After this time, cells were placed on ice for 10 minutes and centrifuged at $10,000 \mathrm{x} \mathrm{g}$ at $4^{\circ} \mathrm{C}$. Supernatants were transferred to a new tube and pellets were solubilized with $1 \mathrm{~mL}$ of $0.05 \%$ Triton X-100 (Sigma Cat. \# T 9284). Sixty microliters of the supernatants and solubilized pellets were incubated at $37^{\circ} \mathrm{C}$ together with $20 \mu \mathrm{l}$ of $0.1 \mathrm{M}$ 4-nitrophenyl-Nacetyl- $\beta$-D-glycosaminide (PNAG, Sigma, Cat. \#N9376) prepared in $0.1 \mathrm{M}$ citrate buffer $(\mathrm{pH} 4.5,0.1 \mathrm{M}$ citric acid and $0.1 \mathrm{M}$ sodium citrate). After 1 hour, the reaction was stopped by the addition of $120 \mu \mathrm{l}$ of a solution containing $0.1 \mathrm{M}$ $\mathrm{Na}_{2} \mathrm{CO}_{3} / \mathrm{NaHCO}_{3}$. Light absorbance was measured at 405 $\mathrm{nm}$ in an ELISA plate reader. The amount of $\beta$-hexosaminidase release was determined by dividing the activity observed in the supernatant by the total activity of the enzyme, detected in the supernatant plus cell pellet.

\section{RNA Isolation and RT-PCR}

After sensitization, cells were collected and suspended in Tyrode's / BSA at $37^{\circ} \mathrm{C}$. Aliquots of $2 \times 10^{6} \mathrm{IgE}$-sensitized cells in $1 \mathrm{~mL}$ of Tyrode's buffer were then stimulated by the addition of different concentrations of DNP-HSA for one hour. After this time, cells were placed on ice for 10 minutes and centrifuged at $10,000 \mathrm{xg}$ at $4^{\circ} \mathrm{C}$. Cell pellet was used for total RNA extraction using TRI-Reagent (Sigma, Cat. \#T3934). RNA pellets were suspended in $50 \mu \mathrm{l}$ of RNA Secure solution (Ambion, Cat. \#7010) and quantified by light absorption at $260 \mathrm{~nm}$. First strand cDNA synthesis was performed using the First Strand Synthesis Kit from Invitrogen (Cat. \#11904-018). Two microliters from each final reaction were used to amplify the murine isoforms of VEGF or the gliceraldehyde 3-phosphate dehydrogenase (GAPDH) as a control. Primers used for RT-PCR were the following: VEGF sense, 5’ACA TCT TCA AGC CGT CCT GTG TGC
3; antisense, 5'AAA TGG CGA ATC CAG TCC CAG GAG 3; GAPDH sense 5' TGA-AGG-TCG-GTG-TGA-ACGGAT-TTG-GC 3 and antisense 5'CAT-GTA-GGC-CATGAG-GTC-CAC-CAC $3^{\prime}$. In the case of primers for VEGF, they were able to amplify the three main isoforms of VEGF (120, 164, and 188 aminoacids) expressed in mice [25]. Amplification conditions were standardized changing amounts of cDNA, oligonucleotide concentration, annealing temperature and the number of cycles starting from the protocol reported in Ref. 25. We found that the linear range of amplification of the three isoforms was between 24 to 32 cycles. 28 cycles were used to get the best results and good detection, running one fifth of the PCR reaction volume in each lane of agarose gels. PCR conditions were as follows: hot start at $94^{\circ} \mathrm{C}(5 \mathrm{~min})$, denaturation at $94^{\circ} \mathrm{C}(1 \mathrm{~min})$, annealing at $60^{\circ} \mathrm{C}(2 \mathrm{~min} 30 \mathrm{sec})$ and extension at $72^{\circ} \mathrm{C}(4 \mathrm{~min})$ for 28 cycles. PCR products were separated by $2 \%$ agarose gel electrophoresis and were visualized by ethidium bromide staining. A 100-bp DNA ladder was included every time as a reference marker. Densitometric analysis of band intensity was performed using an image analyzer (UVP BioImaging Systems, EpiChemi ${ }^{3}$ Darkroom), and the LabWorks 4.0 Image Acquisition and Analysis Software (UVP BioImaging Systems).

\section{ELISA}

VEGF secretion after antigen stimulation of sensitized cells was analyzed using specific ELISA kits. After sensitization, cells were washed once and suspended in fresh media containing a protease inhibitor cocktail (Roche, Cat. \#1836153, one tablet per $50 \mathrm{~mL}$ of media). Aliquots of $5 \mathrm{x}$ $10^{6}$ cells were incubated at $37^{\circ}$ for distinct times in the absence or presence of $27 \mathrm{ng} / \mathrm{mL}$ DNP-HSA. After each time, supernatants were collected and frozen. Secreted VEGF was analyzed with a mouse VEGF ELISA kit (Biosource International, Cat. \# KMG0112) according to manufacturer's instructions. The limit of detection of the assay was 7.5 $\mathrm{pg} / \mathrm{ml}$. All measurements were performed by triplicate. This assay is reported to show no detectable cross-reactivity with a range of other growth factors and cytokines.

\section{Determination of VEGF Activity}

Mast cell-derived VEGF activity was assayed by western blot, detecting the tyrosine phosphorylation VEGFR-2 receptor after mast cell supernatant addition to Human Vascular Endothelial Cells (HUVECs). Briefly, HUVEC-2 cells (BD Biosciences, Cat. \# 354151) were incubated overnight in serum-free media. The next day, cells were plated in 12 well plates and incubated for 5 minutes with $0.1 \mathrm{mM} \mathrm{Na}_{3} \mathrm{VO}_{4}$. Then cells were stimulated for 5 minutes at $37^{\circ} \mathrm{C}$ with VEGF-containing supernatants obtained from stimulated mast cells, washed and suspended in lysis buffer $(1 \%$ Triton $\mathrm{X}-100,10 \mathrm{mM}$ Tris/HCl, pH 7.6, $150 \mathrm{mM} \mathrm{NaCl}, 30 \mathrm{mM}$ sodium pyrophosphate, $50 \mathrm{mM}$ sodium fluoride and $2 \mu \mathrm{g} / \mathrm{ml}$ of aprotinin). Total protein was separated by SDS-PAGE. VEGFR-2 phosphorylated protein was detected using a monoclonal anti-phospho-VEGFR-2-Tyr 1175 (Cell Signaling Technologies 19A10 rabbit mAb, Cat. \#24785).

\section{Statistical Analysis}

All data shown are expressed as the mean \pm SEM, of at least three independent experiments. Statistical analysis was 

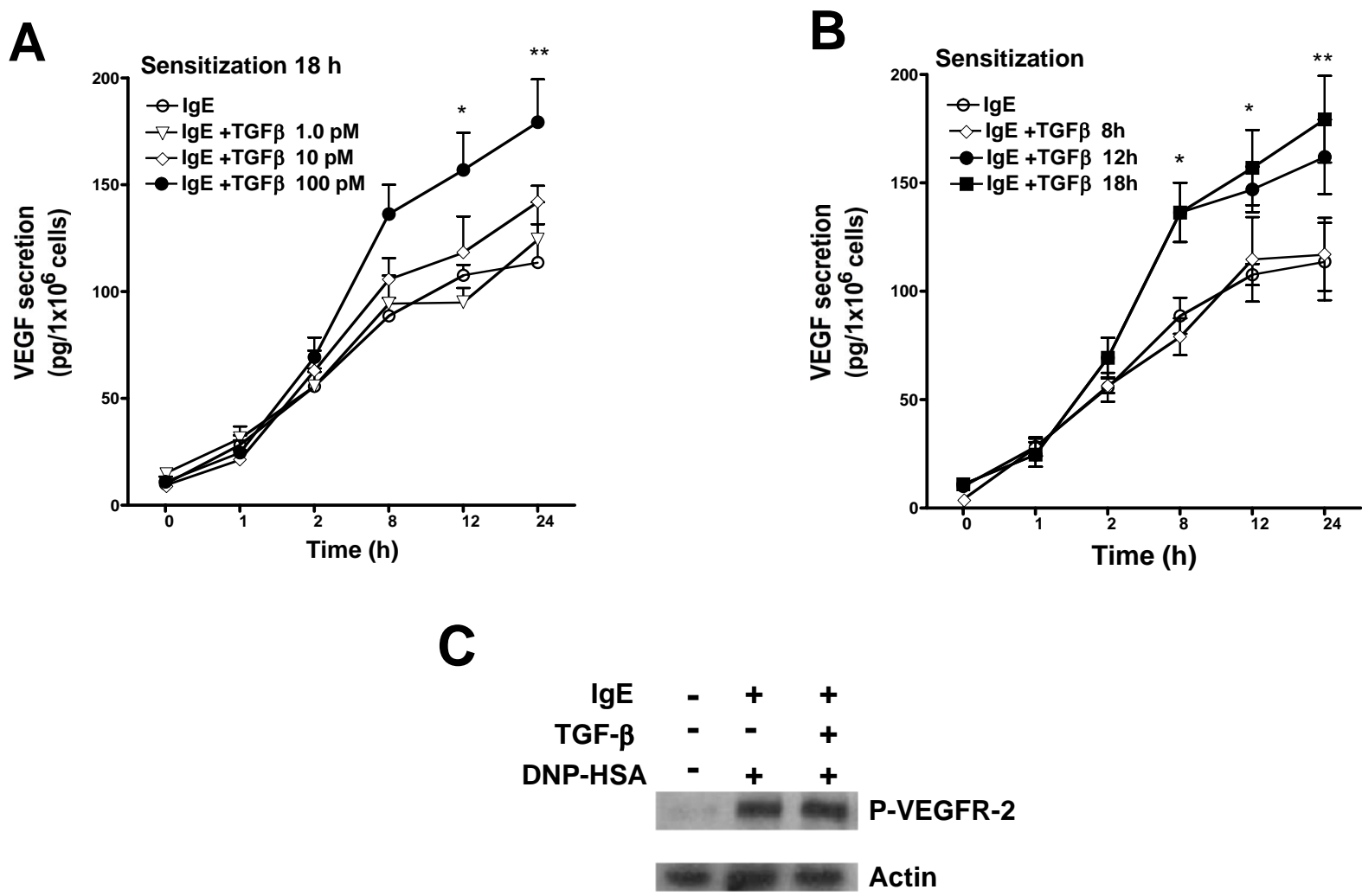

Fig. (1). TGF $\beta$ presence during IgE-dependent sensitization of mast cells increases the release of active VEGF after FceRI stimulation. Panel A. BMMCs were sensitized for 18 hours with $\operatorname{IgE}(300 \mathrm{ng} / \mathrm{ml})$ alone or in combination with different concentrations of TGF $\beta$. After this time, cells were washed once and suspended in fresh media containing $27 \mathrm{ng} / \mathrm{ml}$ of DNP-HSA. Supernatants were collected at different times of incubation at $37^{\circ} \mathrm{C}$. VEGF concentration on the supernatants was determined by ELISA. Panel B. BMMCs were incubated in the presence of $\operatorname{IgE}(300 \mathrm{ng} / \mathrm{mL})$. TGF $\beta(100 \mathrm{pM})$ was added at different times before the 18 hours-long sensitization process concluded. Cells were then collected and stimulated with $27 \mathrm{ng} / \mathrm{ml}$ of DNP-HSA at $37^{\circ} \mathrm{C}$. Supernatants of antigen-activated cells were taken at different times after antigen addition. Data are expressed as the mean \pm SEM from three different experiments using distinct cell cultures. $*$ p $<0.05 ; * * p<0.01$, with respect to IgE-sensitized cells. Panel C. Supernatants containing $50 \mathrm{pg} / \mathrm{ml}$ of VEGF (measured by ELISA) were collected from IgE or IgE+TGF $\beta$-sensitized cells after 8 hours of antigen stimulation. Supernatants were then added to HUVEC cells for 5 minutes. After this time, cells were lysed and phosphorylation of VEGFR2 was detected by western blot as described in Material and Methods section. A representative experiment (of three performed) is shown.

calculated using SigmaStat software (SYSTAT, 2004). Differences between groups were considered significant at $\mathrm{p}<0.05$.

\section{RESULTS}

TGF $\beta$ Presence During Mast Cell Sensitization Increases the Secretion of Functional VEGF after Fce RI Receptor Crosslinking

The influence of TGF $\beta$ during the sensitization step on the VEGF secretion elicited by FceRI receptor activation was analyzed by incubating BMMCs for 18 hours in the presence of a monoclonal anti-dinitrophenol (DNP) immunoglobulin $\mathrm{E}$ (IgE), or with $\mathrm{IgE}$ plus different concentrations of TGF $\beta$. After sensitization, cells were stimulated with the artificial antigen DNP-HSA and VEGF secretion at different time points was measured using a specific ELISA kit. As is shown in Fig. (1A), VEGF accumulation was maximal between 8 and 12 hours after antigenstimulation of BMMCs and the presence of $100 \mathrm{pM}$ TGF $\beta$ induced a significant increase on VEGF secretion after FceRI triggering $(50 \%$ increase over the observed value in IgE-sensitized cells at $12 \mathrm{~h}$ ). This increased VEGF secretion was evident even at 24 hours after antigen addition. In order to find the time necessary to observe the effect of TGF $\beta$, BMMCs were sensitized with IgE for $18 \mathrm{~h}$ or with $\operatorname{IgE}$ plus TGF $\beta$ added at different times prior to antigen stimulation. As can be observed in Fig. (1B), it was necessary the presence of TGF $\beta$ for 12 to 18 hours prior to antigen stimulation to observe the increase on VEGF secretion. VEGF produced by $\operatorname{IgE}$ or $\operatorname{IgE}+\mathrm{TGF} \beta$-sensitized cells was equally potent to provoke phosphorylation of VEGFR2 in HUVEC cells (Fig. 1C). This phosphorylation was prevented by the addition of a neutralizing antibody against VEGF to mast cells supernatants prior to HUVEC stimulation (data not shown).

TGF $\beta$ Presence During Mast Cell Sensitization Does Not alter the Apoptotic Rate of BMMCs or the IgEDependent up Regulation of Fce RI Receptor Expression in Plasma Membrane

Since it has been shown that TGF $\beta$ can influence cell proliferation in different cell types [26], we investigated if the sensitization with IgE+TGF $\beta$ could modify mast cell apoptosis. We sensitized mature BMMCs cells with $\operatorname{IgE}$ or $\operatorname{IgE}+\mathrm{TGF} \beta$ for 18 hours and the apoptotic populations in the culture were detected by the expression of annexin $\mathrm{V}$ and 
propidium iodide permeability. Fig. (2A) shows a representative dot plot of BMMCs after $18 \mathrm{~h}$ of sensitization with $\mathrm{IgE}$ or IgE+TGF $\beta$. Early (annexin V positive; propidium iodide negative), or late (annexin $\mathrm{V}$ positive; propidium iodide positive) apoptotic cells were found without change in cells sensitized with IgE or with IgE+TGF $\beta$ for 18 hours. Percentages of annexin $\mathrm{V}$ positive cells in $\mathrm{IgE}$ condition versus IgE+TGF $\beta$ were $25 \% \pm 10 \%$ vs. $32 \% \pm 14 \%$ (mean values \pm SEM, $\mathrm{n}=3$ ), and PI positive cells in IgE condition versus $\operatorname{IgE}+\mathrm{TGF} \beta$ were $6 \% \pm 4 \%$ vs. $5 \% \pm 2 \%$; double positive (late apoptotic) cells did not show any change in the presence of TGF $\beta$, since there were $2.5 \pm 0.6 \%$ of the total population, an usual value obtained from this type of primary culture [27]. Total cell numbers were found without change after the 18 hours-long incubation with $\operatorname{IgE}$ or $\operatorname{IgE}+\mathrm{TGF} \beta$, suggesting no important effect on cell proliferation (data not shown). In order to explore if sensitization of mast cells with IgE+TGF $\beta$ could induce changes on the amount of FceRI receptor at the plasma membrane, we analyzed FceRI receptor expression using flow cytometry. As can been observed in Fig. (2B), the 18 hours-long sensitization period with $\operatorname{IgE}$ alone was able to induce the well-documented increase of FceRI in the plasma membrane of mast cells [3], and this increase was not modified by the presence of 100 pM TGF $\beta$. In order to test if sensitization with $\operatorname{IgE}+\mathrm{TGF} \beta$ could change the capacity of FceRI to trigger degranulation, $\beta$ hexosaminidase release was measured after antigen addition in $\operatorname{IgE}$ or IgE+TGF $\beta$ sensitized cells. Fig. (2C) shows that degranulation triggered by antigen addition was not altered in cells sensitized in the presence of TGF $\beta$.

IgE-TGF $\beta$-Sensitized Mast Cells Secrete VEGF after Fce RI Crosslinking Trough a Transcription-Independent Mechanism

VEGF production in different cell types involves de novo transcription, mRNA stabilization and/or differential processing of the protein [28]. In order to analyze the mechanism by which VEGF production was increased after antigenic stimulation of IgE+TGF $\beta$ sensitized cells, we tested the effect of the transcription inhibitor Actinomycin D (ActD) on FceRI-induced VEGF secretion. Fig. (3) shows VEGF secretion in IgE-(left panel) and IgE+TGF $\beta$-sensitized cells (right panel) after FceRI crosslinking in the presence/absence of ActD $(5 \mu \mathrm{g} / \mathrm{mL})$. Cells were sensitized for 18 hours, washed once, and incubated with the inhibitor $15 \mathrm{~min}$ before antigen addition. VEGF secretion was evaluated at different times after stimulation. It was possible to observe that FceRI crosslinking induces VEGF secretion through a mechanism sensitive to ActD on IgE-sensitized cells, whereas the processes involved on VEGF production in IgE+TGF $\beta$ sensitized cells was insensitive to the transcription inhibitor. Cell viability (determined by trypan blue exclusion) was not altered by the longest time of incubation with ActD (data not shown).

\section{Sensitization of Mast Cells in the Presence of TGF $\beta$ Causes a Marked Increase on VEGF mRNA Half-Life after IgE-Antigen Stimulation}

Since VEGF secretion in IgE+TGF $\beta$ sensitized cells was not prevented by ActD pre-treatment, we decided to evaluate VEGF mRNA turnover after FceRI stimulation using primers able to amplify the three main isoforms of VEGF
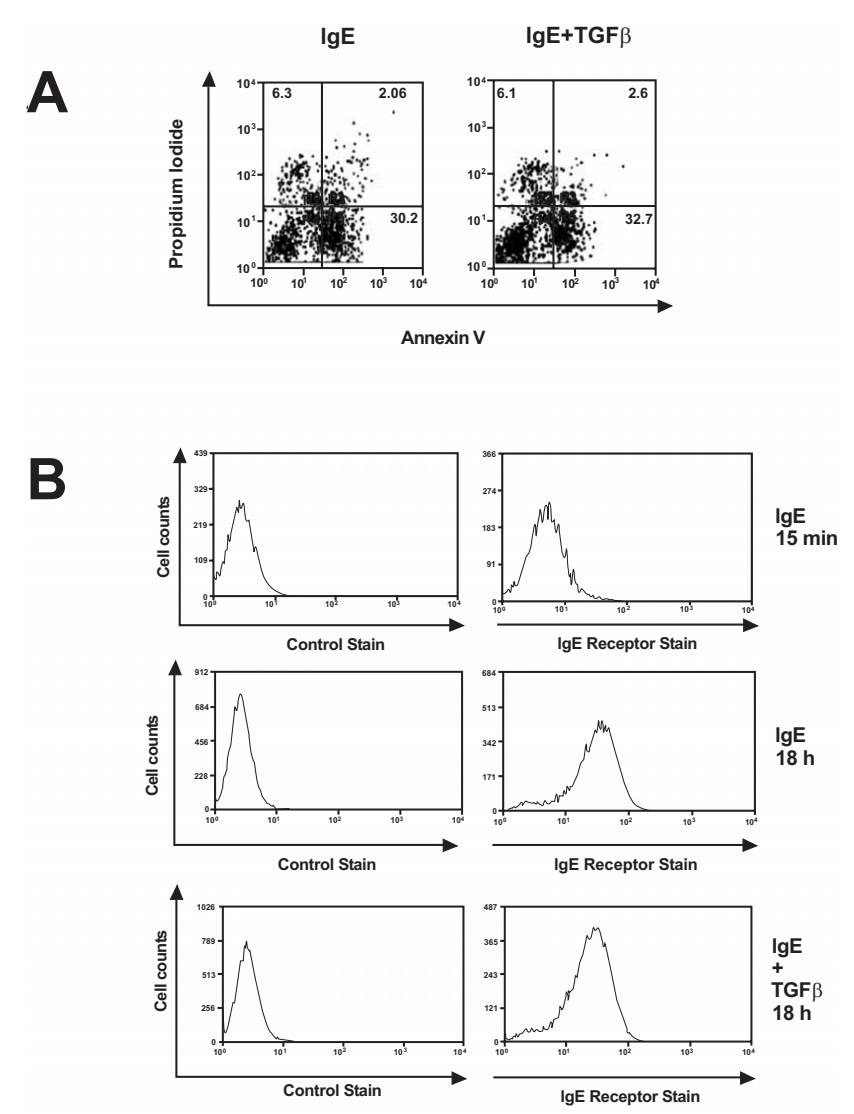

C

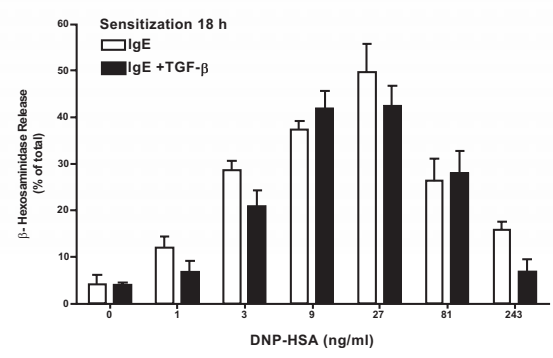

Fig. (2). TGF $\beta$ presence during IgE-dependent sensitization of mast cells does not induce apoptosis neither modify FceRI receptor expression or antigen-induced degranulation. Panel A. BMMCs were incubated $18 \mathrm{~h}$ with $\operatorname{IgE}$ or with $\operatorname{IgE}+\mathrm{TGF} \beta$. After treatment, cells positive to propidium iodide, annexin $\mathrm{V}$ or both, were analyzed by flow cytometry. Numbers inside the graphs show the percentage of cells in each region of a representative experiment (of three performed). Panel B. BMMCs were incubated with $\operatorname{IgE}$ during 15 minutes or $18 \mathrm{~h}$, or with IgE+TGF $\beta$ for $18 \mathrm{hr}$. FceRI expression was assessed by flow cytometry using a FITC-labeled isotype control antibody (left histograms) or a specific FITC-coupled anti-IgE antibody (right histograms). A representative result from three different experiments using distinct BMMC cultures is shown in each case. Panel C. BMMCs were sensitized with $\operatorname{IgE}$ or IgE+TGF $\beta$ during $18 \mathrm{~h}$. After this time, cells were stimulated with different concentrations of DNP-HSA and $\beta$ hexosaminidase release was determined as described in the Material and Methods section. Data are expressed as the means \pm SEM from three different experiments using distinct cell cultures. 

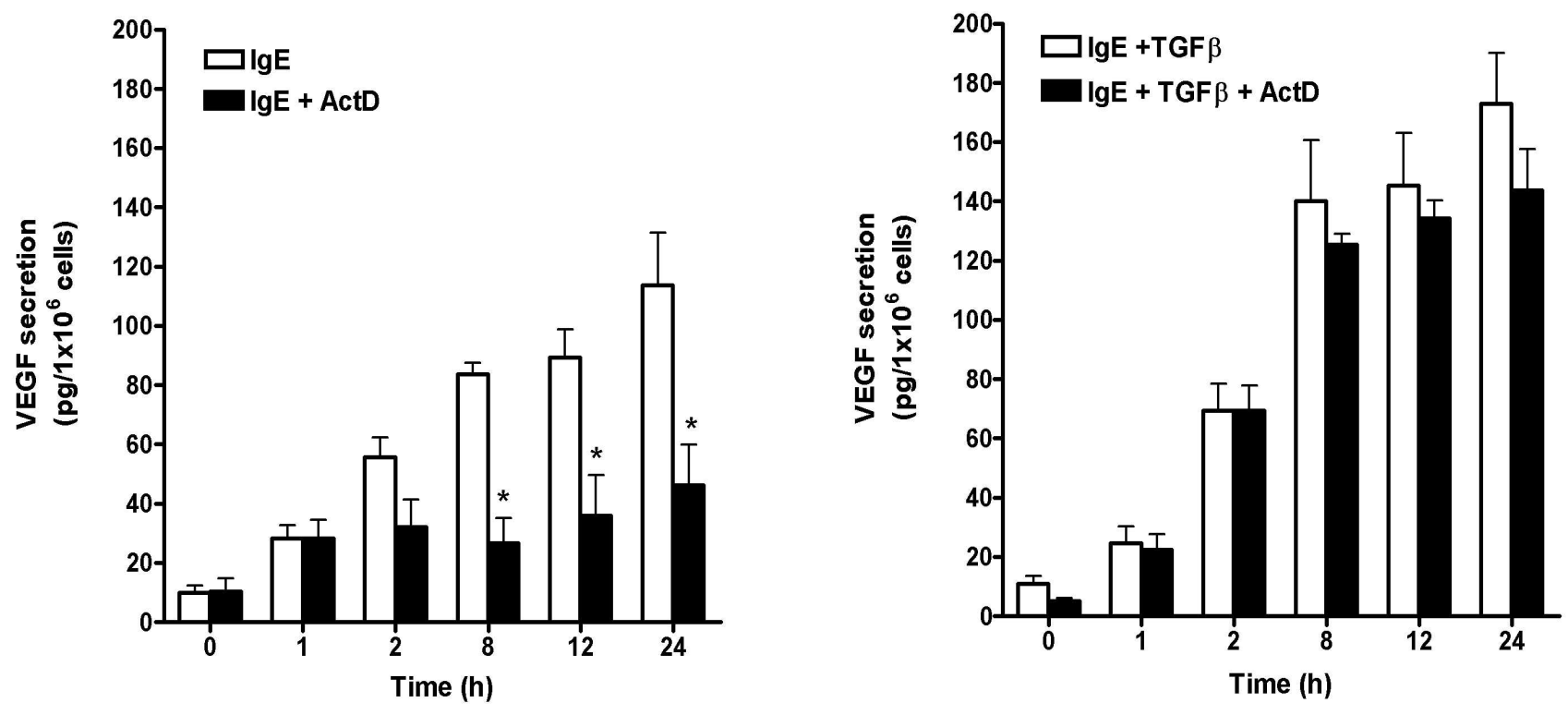

Fig. (3). BMMC sensitization with IgE+TGF $\beta$ causes antigen-induced secretion of VEGF in a transcription-independent fashion. BMMCs were sensitized $18 \mathrm{~h}$ with IgE (left panel) or IgE+TGF $\beta$ (right panel) and after that, cells were washed once and suspended in fresh media containing (or not) $5 \mu \mathrm{g} / \mathrm{mL}$ Actinomycin D (ActD) for 15 minutes. Then, antigen $(27 \mathrm{ng} / \mathrm{mL})$ was added and supernatants were taken at different times of incubation at $37^{\circ} \mathrm{C}$. VEGF concentration was determined using specific ELISA kits. Data are expressed as the means \pm SEM from three different experiments using distinct cell cultures. ${ }^{*} \mathrm{p}<0.05$, with respect to IgE-sensitized cells.

expressed in mice $\left(\mathrm{VEGF}_{120}, \mathrm{VEGF}_{164}\right.$ and $\left.\mathrm{VEGF}_{188}\right)$. Fig. (4) shows that VEGF mRNA is abundant in BMMCs and its half-life is short $(\approx 25 \mathrm{~min})$ in non-sensitized/non stimulated cells, indicating a continuous synthesis and degradation of VEGF mRNA. IgE and IgE+TGF $\beta$-sensitized cells were treated with antigen in order to activate FceRI signaling system and, 15 minutes later, ActD was added in order to stop de novo transcription. Total RNA was isolated at different times after ActD addition and remaining VEGF mRNA was detected by RT-PCR. In those conditions, the amount of VEGF mRNA induced by 15 min of antigen stimulation in IgE sensitized mast cells was not different from the basal observed in non-sensitized, non-stimulated mast cells (lane 1 vs lane 5 on Fig. 4A). However, it was possible to observe a marked stabilization of VEGF mRNA induced by antigen stimulation in IgE-sensitized mast cells (VEGF mRNA halflife $>100 \mathrm{~min})$. Interestingly, in cells sensitized with IgE+TGF $\beta$, VEGF mRNA half-life was increased to more than $3 \mathrm{~h}$ after FceRI stimulation. This result suggests that presence of TGF $\beta$ during the IgE-dependent sensitization of mast cells induce changes on the FceRI signal transduction system allowing to an increased VEGF mRNA stabilization after antigenic stimulation.

\section{VEGF Secretion and mRNA Stabilization after Fce RI Crosslinking Depends on p38 MAPK Activity}

It has been reported that activation of different MAPK, in particular p38, controls VEGF mRNA half life [29]. In order to characterize the pathway responsible for VEGF mRNA stabilization in IgE-antigen activated mast cells, we decided to explore the participation of p38 MAPK using the selective inhibitor SB202190 [30]. IgE or IgE+TGF $\beta$ sensitized mast cells were treated with different concentrations SB202190 for 15 minutes. Then, antigen was added and VEGF secretion was measured in cell supernatants after 8 h (Fig. 5A). Incubation with SB202190 previous to antigen stimulation was able to block FceRI-induced VEGF secretion in both IgE and IgE+TGF $\beta$ sensitized cells and the inhibition was evident at micromolar concentrations of the compound. Differences on sensitivity to SB202190 were noticed between IgE and IgE+TGF $\beta$ sensitized cells; a detailed analysis of the inhibition was performed and is presented in the inset of Fig. (5A), where it can be observed that the slope of the straight line obtained with the inhibition data was -0.65 for IgE-sensitized cells and -0.96 for IgE+TGF $\beta$. Those results indicate that FceRI-induced VEGF secretion in IgE+TGF $\beta$ sensitized cells is more sensitive to SB202190 than the observed in IgE alone-sensitized BMMCs. This increased sensitivity was evident at $0.1 \mu \mathrm{M}$ SB202190, where the difference between inhibitor-free and inhibitor-treated IgE+TGF $\beta$ sensitized cells showed statistical significance, whereas that was not the case for inhibitor free and inhibitortreated IgE-sensitized cells.

In a second group of experiments, $\operatorname{IgE}$ and $\operatorname{IgE}+\mathrm{TGF} \beta$ sensitized cells were treated with $10 \mu$ M SB202190 for 15 minutes before the addition of antigen. Antigen was added and 15 min later, ActD was added in order to stop de novo gene transcription. Cell samples were taken at different times after ActD addition and total RNA was purified in order to detect the amount of VEGF mRNA by RT-PCR. As can be observed in Fig. (5B), pretreatment with SB202190 did not change the amount of basal or $15 \mathrm{~min}$ antigen-induced VEGF mRNA accumulation, however, it was able to prevent the observed stabilization of VEGF mRNA in both IgE and IgE+TGF $\beta$ sensitized cells after antigen stimulation.

\section{DISCUSSION}

Diverse and sometimes contradictory effects of TGF $\beta$ on immune cells have been reported. The role of TGF $\beta$ as a suppressor of immunity and inflammation is supported by a number of studies showing the inhibitory effects of TGF $\beta$ on 


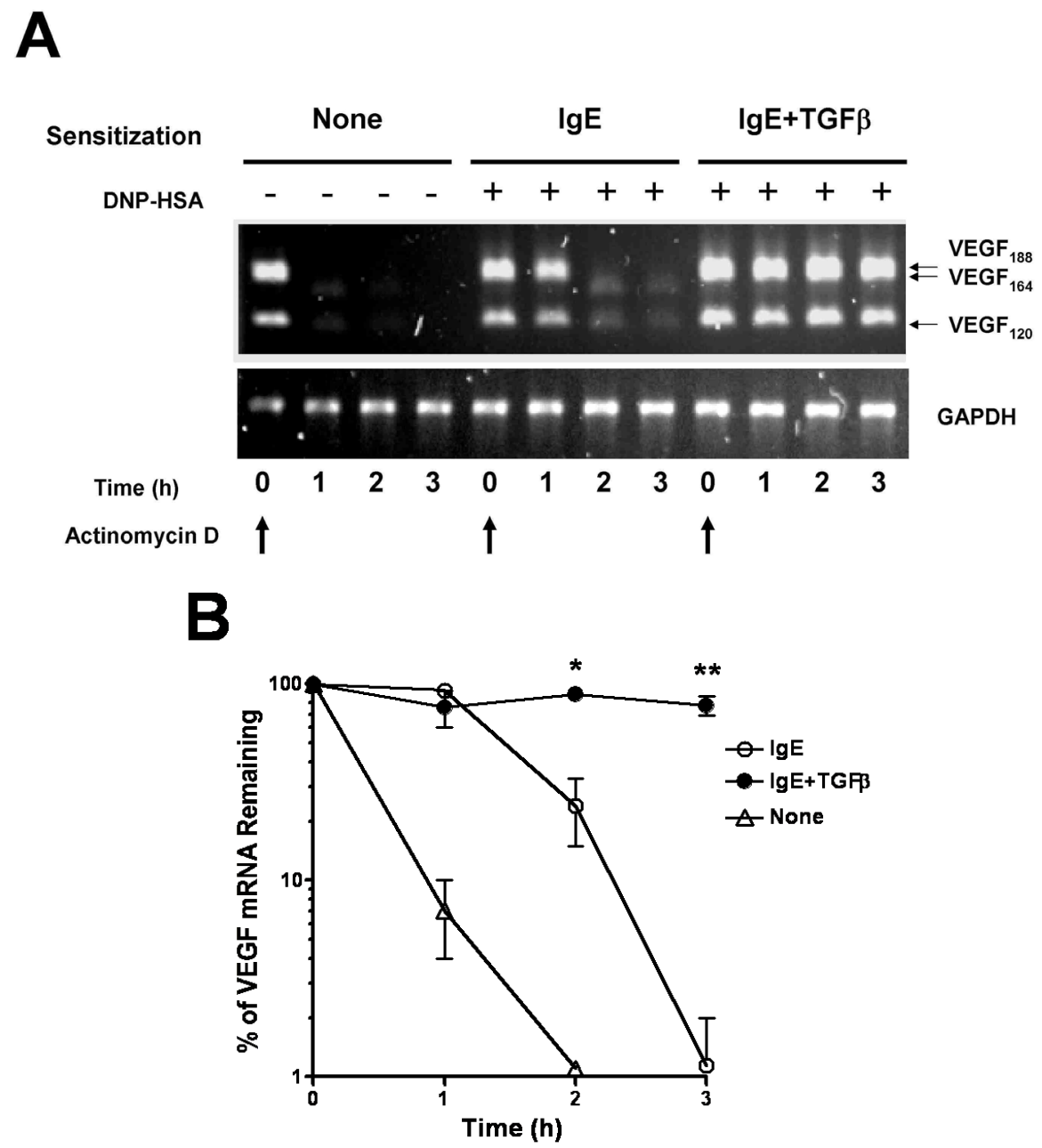

Fig. (4). TGF $\beta$ presence during IgE-dependent sensitization of mast cells causes an increase on VEGF mRNA half-life after FceRI stimulation. Panel A. BMMCs growing in complete media were treated $18 \mathrm{~h}$ with none, IgE or IgE+TGF $\beta$. After this time, cells were washed once and suspended in new media containing $27 \mathrm{ng} / \mathrm{ml}$ DNP-HSA for 15 minutes before the addition of $5 \mu \mathrm{g} / \mathrm{mL}$ ActD. Cell samples were taken at different times after ActD addition and RT-PCR was performed as described in the Material and Methods section. Results of a representative experiment (from three performed with different cultures) are shown. Panel B. Densitometric analysis of the bands obtained in panel A was performed and results were used to construct a graph showing VEGF mRNA decay. VEGF signal was normalized to its respective GAPDH intensity value. Values at $\mathrm{t}=0$ after ActD addition on panel $\mathbf{A}$ were taken as $100 \%$. Data are expressed as the means \pm SEM from three different experiments using distinct cell cultures. $* \mathrm{p}<0.05$ and $* * \mathrm{p}<0.01$, with respect to IgE-sensitized cells.

immune cell function, including mast cells [8]. Long-term mast cell culture in the presence of TGF $\beta$ provoked low expression of FceRI in the plasma membrane and impaired IgE-mediated cytokine secretion after antigenic stimulation [31]; TGF $\beta$ was also able to inhibit IL-3 and IL-4 dependent mouse connective tissue mast cell proliferation [32]; also, TGF $\beta$-induced alterations in proliferation of BMMC cultures without any change in mast cell function have been reported [33]. On the other hand, an increase on some of the IgEantigen-elicited responses in mast cells has been documented. Shorter $(16 \mathrm{~h})$ periods of mast cell exposure to TGF $\beta$ have been shown to promote an increased lymphotactin mRNA production after FceRI crosslinking [34]. The increase of FceRI-induced synthesis of lipid mediators, such as leukotriene (LT)A $4, \mathrm{LTB}_{4}, \mathrm{LTC}_{4}$ and 6-trans $\mathrm{LTB}_{4}$ after TGF $\beta$ treatment, without any modification on $\beta$-hexosaminidase release has been observed [35]. Different circumstances can explain the contradictory effects of TGF $\beta$ on FceRI-induced responses in mast cells. Distinct times and concentrations of TGF $\beta$ have been used in each study; distinct amounts of $\mathrm{IgE}$ and diverse protocols of sensitization have been used too. It is possible that the final effects of TGF $\beta$ depend on the utilized doses and the presence/absence of IgE during long periods of time. In our experiments, a positive influence of TGF $\beta$ on FceRI-induced VEGF secretion was observed when saturating amounts of IgE were used, at the same time, to sensitize mast cells. The observed effect was not related to apparent changes on mast cell apoptotic rate or IgE-receptor expression in plasma membrane (Fig. 2).

Different molecular mechanisms can contribute to the increase in VEGF secretion after FceRI triggering and some of them could be modified by the presence of TGF $\beta$ during the sensitization phase of mast cells. As can be observed in Fig. (3), VEGF secretion after FceRI crosslinking strongly depends on de novo transcription in IgE-sensitized cells, whereas in IgE+TGF $\beta$-sensitized cells the contribution of 
transcription seems to be discrete. These results suggest that TGF $\beta$ presence during the sensitization phase of mast cells causes a remodeling of the pathway that controls VEGF secretion after FceRI crosslinking, altering the mechanisms responsible for VEGF mRNA stability or protein synthesis/secretion. Studies about the molecular events leading to VEGF production after FceRI receptor crosslinking in mast cells are scarce, but some information can be taken from experiments done in hypoxic conditions in other cell types. Induction of VEGF during hypoxia depends on the activation of HIF transcription factor, which is able to increase VEGF mRNA amounts 2-3 times [28]. However, VEGF production also depends on the activation of several post-transcriptional mechanisms leading to VEGF mRNA stabilization in the cytoplasm, producing an increase in VEGF mRNA half life by a factor of 3, resulting in 8-30 times higher levels of VEGF mRNA [36].

Since VEGF is tightly regulated at post-transcriptional level, we decided to explore VEGF mRNA turnover after antigenic stimulation in cells sensitized with $\operatorname{IgE}$ or IgE+TGF $\beta$ and, as a control, we determined VEGF mRNA half-life in non-sensitized/non stimulated cells too. Notably, the amount of VEGF mRNA induced by $15 \mathrm{~min}$ of antigen IgE-sensitized mast cells was not different from the basal observed in non-sensitized, non-stimulated conditions (lane 1 vs lane 5 on Fig. 4A), indicating that sensitization with monomeric IgE does not modify basal VEGF mRNA accumulation and that transcriptional activation of VEGF is not evident at short times $(15 \mathrm{~min})$ after antigenic stimulation. The main effect of the presence of antigen in IgE-sensitized cells seemed to be the increased half-life of VEGF mRNA, suggesting that binding of monomeric IgE to its receptor during the sensitization step could induce some changes on the mast cell apparatus controlling inflammatory mRNA accumulation after antigenic stimulation, leaving the cells able to inhibit normal rates of mRNA degradation or allowing the production of proteins able to stabilize distinct mRNA molecules. IgE binding once was though to be a passive step which would keep mast cells in a "prepared" state before receptor aggregation with multivalent allergens, but this view of the sensitization process has been challenged after the findings showing that receptor- $\mathrm{IgE}$ interaction can promote several changes on mast cell activity, such as up regulation of cell surface expression of $\mathrm{IgE}$ receptor, selective cytokine production and survival of mast cells [37]. Our results provide evidence suggesting those changes could include the synthesis of post-transcriptional regulators of cytokine synthesis.

Interestingly, the presence of TGF $\beta$ during the sensitization step significantly improved VEGF mRNA stabilization after antigenic stimulation. TGF $\beta$-induced stabilization of COX-2, thrombospondin, parathyroid hormone, ribonucleotide reductase R2 subunit, amyloid precursor protein, and the hyaluronan receptor mRNAs by activation of Smaddependent and independent pathways has been reported [38]. Since no change on basal levels of VEGF mRNA was observed in cells sensitized with $\operatorname{IgE}+\mathrm{TGF} \beta$ (Fig. 4), a direct effect of TGF $\beta$ on basal mRNA stabilization cannot be claimed, but it is possible that during the period of sensitization, TGF $\beta$ could synergize with monomeric IgE for the production of specific proteins leading to mRNA stabilization after FceRI crosslinking. Distinct proteins have been involved on VEGF mRNA stability control. HuR (a member of the embryonic lethal abnormal vision, ELAV, family) [39], tristetrapolin (TTP), and other factors [40] are able to bind and control VEGF mRNA half-life in different conditions. Changes on their synthesis, activation or subcellular localization due to TGF $\beta$ presence could explain the changes observed on VEGF mRNA.

VEGF mRNA half-life was increased more than three times after antigen stimulation in IgE+TG $\beta$-sensitized cells (Fig. 4). However, the increase on VEGF secretion was not of the same magnitude $(50 \%$ increase respect to IgE-alone sensitized cells, Fig. 1). These results suggest other posttranscriptional processes, such as translational efficiency or selective secretion can contribute to VEGF production in mast cells. It has been reported that, although 3'ARE containing mRNAs are highly stabilized by HuR binding in the cytoplasm, those messengers do not co-localize with the polysomal fraction in cell extracts and its translation is not proportionally increased [41]. Although VEGF has been found inside histamine-containing granules in mast cells [23] slower mechanisms of secretion, like piecemeal degranulation [42] could participate in VEGF production in mast cells and could be modified during the sensitization process. Future experiments analyzing the intracellular VEGF content in sensitized mast cells, its secretion rate and the effects on the formation of new blood vessels in allergic inflammation, will give light on the mechanism and the biological consequences of the observed effects of TGF $\beta$.

p38 MAPK has been reported to be important for VEGF, TNF- $\alpha$ and IL- $1 \beta$ mRNA stabilization [43]. Pretreatment of BMMCs with SB202190 was able to block the FceRIdependent phosphorylation of the ATF-2 transcription factor, a well recognized downstream effector of p38 pathway (data not shown). As can be observed in Fig. (5), SB202190 pretreatment did not modify the amount of VEGF mRNA after 15 minutes of antigenic stimulation, but it was able to block the previously observed antigen-induced mRNA stabilization (Fig. 5), indicating the participation of p38 MAPK on the pathway connecting FceRI receptor with VEGF mRNA turnover. Two important substrates of p38 $\alpha$ are the MAP kinase-activated protein kinase 2 (MAKAP2 or MK2) and the closely related family member (MK3) [44]. When these substrates are phosphorylated, they have been shown to activate various proteins and, particularly, MK2 has been found to phosphorylate TTP, altering TNF- $\alpha$ mRNA half- life [45]. Interestingly, VEGF secretion in IgE+TGF $\beta$-sensitized cells seemed to be more sensitive to the effects of SB202190 than the observed in IgE alone-sensitized cells (Inset Fig. 5), suggesting an important effect of TGF $\beta$ in the induction of $\mathrm{p} 38$ dependent pathways leading to mRNA stabilization. Accordingly with the positive role of p38 on increased inflammatory cytokine release, IgE+ TGF $\beta$-sensitized cells showed higher TNF- $\alpha$ secretion than IgE-sensitized cells after antigen stimulation, and that increase was blocked by SB202190 (unpublished results).

An important role of TGF $\beta$ in allergic inflammation has been particularly observed in chronic asthma. The chronic inflammatory response in the airway is characterized by the presence of increased numbers of Th2 lymphocytes, eosinophils and activated mast cells. The airways of patients with asthma exhibit varying levels of structural changes (airway 


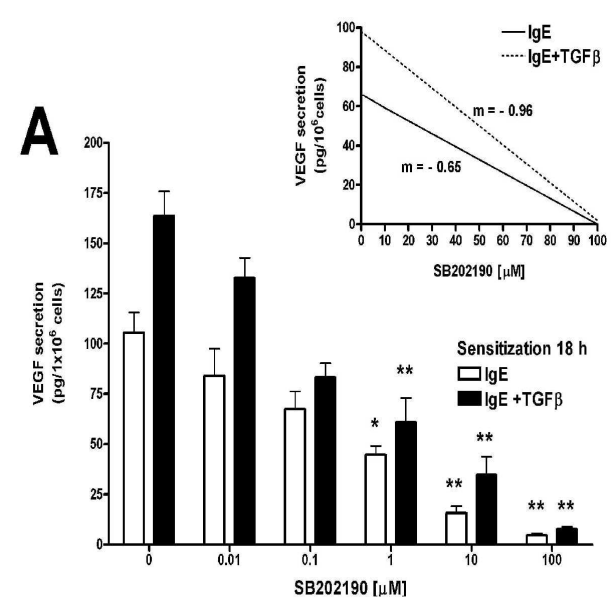

B

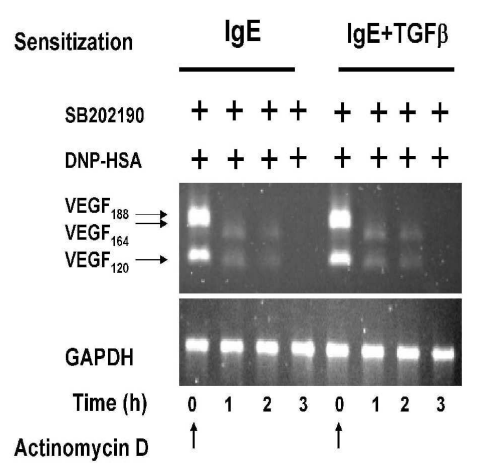

Fig. (5). p38 MAPK activity is necessary for FceRI-dependent VEGF secretion and mRNA stabilization in both IgE and IgE+TGF $\beta$ sensitized mast cells. Panel A. BMMCs were sensitized with $\operatorname{IgE}$ or $\operatorname{IgE}+\mathrm{TGF} \beta$ for 18 hours. Cells were then washed once and suspended in fresh media containing vehicle or different concentrations of SB202190. After $15 \mathrm{~min}$ incubation at $37^{\circ} \mathrm{C}$, DNPHSA $(27 \mathrm{ng} / \mathrm{ml})$ was added and cells were incubated for 8 hours at $37^{\circ} \mathrm{C}$ prior to supernatant collection. VEGF concentration in the supernatants was determined by ELISA. Data are expressed as the means \pm SEM from three different experiments using distinct cell cultures. $* * * \mathrm{p}<0.05$ with respect to $\operatorname{IgE}$ sensitized cells, paired t-test, \& $\mathrm{p}<0.05$ with respect to IgE+TGF $\beta$-sensitized, inhibitor free cells; \# p $<0.05$ with respect to IgE-sensitized, inhibitor free cells, one way ANOVA. Inset. Linear least squares regression performed using values from the shown bar graph. Equation for IgE-sensitized cells was $y=-0.657(x)+65.79$; for IgE+TGF $\beta$-sensitized cells, equation was $y=-0.963(x)+98.17$. Panel B. BMMCs were sensitized 18 $\mathrm{h}$ with IgE or IgE+TGF $\beta$. Then, cells were washed once and suspended in new media containing vehicle or $10 \mu \mathrm{M} \mathrm{SB} 202190$ for $15 \mathrm{~min}$ at $37^{\circ} \mathrm{C}$. Cells were then stimulated for $15 \mathrm{~min}$ with 27 $\mathrm{ng} / \mathrm{mL}$ DNP-HSA before $5 \mu \mathrm{g} / \mathrm{mL}$ ActD addition ( $\mathrm{t}=0$ ). After ActD addition, cell samples were taken at different times and RT-PCR was performed as described in the Material and Methods section. Results of a representative experiment (of three performed in with different cultures) are shown.

remodeling) that modify lung function. Characteristic structural changes of airway remodeling include epithelial cell mucus metaplasia, smooth muscle hypertrophy/hyperplasia, eosinophilia, subepithelial fibrosis and increased angiogenesis [46]. Recent studies suggest that eosinophil-derived TGF $\beta$ may play an important role in the pathogenesis of airway remodeling [47]. On the other hand, endobronchial biopsies from patients with asthma showed increased numbers of chymase-positive mast cells associated with both increased numbers of blood vessels and increased numbers of cells expressing VEGF compared with healthy control subjects [48]. Co-localization immunohistochemistry studies demonstrated that mast cells are an important source of VEGF [49]. Pulmonary mast cells are sensitized binding allergen-specific IgEs and the release of histamine and inflammatory mediators is triggered by allergen-induced FceRI crosslinking [2]. Our results suggest that TGF $\beta$ presence in lung could modify the IgE-dependent sensitization process, leading to an increase of VEGF secretion after allergen contact. Previous evidence has implied TGF $\beta$ in extracellular matrix deposition in asthma [50], our results indicate that TGF $\beta$ could participate in lung angiogenesis due to its effects on VEGF secretion by mast cells. Interestingly, using an OVA-sensitized rat model of allergic lung inflammation, it has been shown that an inhibitor of TGF $\beta$ receptor type I kinase, has both a preventive and neutralizing effect on airway inflammation, as measured by basic-protein positive eosinophils and CD2+ T-cell counts in mucosal airways, cell proliferation and goblet cell hyperplasia induced by repeated allergen challenges [51], supporting the role of a pro-inflammatory role of TGF $\beta$ in mast cell-dependent inflammatory reactions.

Mast cells are in contact with soluble and matrixassociated TGF $\beta$ during different circumstances, since they finish their differentiation in the presence of microenvironment components in distinct tissues [1]. Mast cells interact to basement membrane during migration and maturation in peripheral tissues, such as the gastrointestinal and genitourinary tracts and the respiratory system. In the road to different locations, TGF $\beta$ induce phenotypic changes, preparing mast cells for posterior increased IgE-antigen-elicited responses [52]. Evidence of increase of mast cell hyperplasia in connection with TGF $\beta$ presence has been found in disorders such as rheumatoid arthritis, pulmonary fibrosis, and cancer, suggesting an important influence of TGF $\beta$ on mast cell maturation, proliferation and signaling [53]. This modulator effect of TGF $\beta$ on FceRI-dependent responses could be exerted also by other local mediators like adenosine, acetylcholine or neuropeptides, present in lung or close to nerve terminals; i.e., a positive effect of thrombin on some IgE/antigen-elicited responses in mast cells has been reported [54].

Our in vitro results suggest that a potentially important synergism between pro-inflammatory actions of TGF $\beta$ and monomeric IgE can occur in different inflammation-related pathologies. Future studies analyzing the molecular remodeling of the FceRI receptor signal transduction system, due the presence of locally produced mediators together with allergen-specific IgEs, will improve our knowledge on the specific allergic responses observed in distinct tissues due to particular microenvironment conditions.

\section{ACKNOWLEDGEMENTS}

Authors wish to thank Dr. Luisa Iruela-Arispe from UCLA for her invaluable help training JPBG on VEGFR 
phosphorylation assays, Hector Vazquez for reference search, Dr. Gloria Gutierrez Venegas for the ATF-2 antibody and Victor Hugo Rosales for technical assistance with FACS experiments. JPBG received a scholarship (No. 183383) and an exchange/travel award from Conacyt. This work was financed by Conacyt, Mexico, Project No. 83079 and Fundacion Miguel Aleman, Mexico.

\section{LIST OF ABBREVIATIONS}

$\begin{array}{lll}\text { BMMC } & = & \text { Bone Marrow-derived Mast Cells } \\ \text { VEGF } & = & \text { Vascular Endothelial Growth Factor } \\ \text { IgE } & = & \text { Immunoglobulin E } \\ \text { FceRI } & = & \text { High Affinity IgE Receptor } \\ \text { TGF } \beta & = & \text { Transforming Growth Factor } \beta \\ \text { VEGFR2 } & = & \text { VEGF Receptor } 2 \\ \text { ARE } & = & \text { AU-rich cis-element }\end{array}$

\section{REFERENCES}

[1] Kinet JP. The essential role of mast cells in orchestrating inflammation. Immunol Rev 2007; 217: 5-7.

[2] Hannah H, Gould HJ, Sutton BJ, et al. The biology of IgE and the basis of allergic disease. Ann Rev Immunol 2003; 21: 579-628.

[3] Kalesnikoff J, Huber M, Lam V, et al. Monomeric IgE stimulates signalling pathways in mast cells that lead to cytokine production and cell survival. Immunity 2001; 14: 801-11.

[4] Saini SS, Klion AD, Holland SM, et al. The relationship between serum IgE and surface levels of FceRI on human leukocytes in various diseases: correlation of expression with FceRI on basophils but not on monocytes or eosinophils. J Allergy Clin Immunol 2000; 106: 514-20.

[5] Rivera J, Gilfillan AM. Molecular regulation of mast cell activation. J Allergy Clin Immunol 2006; 117: 1214-25.

[6] Rivera J. Molecular adapters in FceRI signaling and the allergic response. Curr Opin Immunol 2002; 14: 688-93.

[7] Gonzalez-Espinosa C, Medina-Tamayo J, Sanchez-Miranda E, et al. Signaling through the high affinity IgE receptor and conditions able to modify IgE-antigen responsiveness of mast cells. Signal Transduct 2007; 7: 402-14.

[8] Li MO, Wan YY, Sanjabi S, Robertson AKL, Flavell RA. Transforming growth factor- $\beta$ regulation of immune responses. Ann Rev Immunol 2006; 24: 1-48.

[9] Chang H, Brown CW, Matzuk MM. Genetic analysis of the mammalian transforming growth factor $\beta$ superfamily. Endocr Rev 2002; 23: 787-823.

[10] Torrego A, Hew M, Oates T, Sukkar M, Fan Chung K. Expression and activation of TGF-beta isoforms in acute allergen-induced remodelling in asthma. Thorax 2007; 62: 307-13.

[11] Roskoski R. Vascular endothelial growth factor (VEGF) signaling in tumor progression. Crit Rev Oncol Hematol 2007; 62: 179-213.

[12] Grützkau A, Krüger-Krasagakes S, Baumeister H, et al. Synthesis, storage and release of vascular endothelial growth factor/vascular permeability factor (VEGF/VPF) by human mast cells: implications for the biological significance of $\mathrm{VEGF}_{206}$. Mol Biol Cell 1998; 9: 875-84.

[13] Boesiger J, Tsai M, Maurer M, et al. Mast cells can secrete vascular permeability factor/vascular endothelial cell growth factor and exhibit enhanced release after immunoglobulin E-dependent upregulation of Fc epsilon receptor I expression. J Exp Med 1998; 188: 1135-45.

[14] Szukiewicz D, Szukiewicz A, Maslinska D, Szewczyk G, Watroba M. Mast cell-derived vascular endothelial growth factor (VEGF) and microvascular density in diabetic placentae. Inflamm Res 2003; 52 (Suppl 1): S09-10.

[15] Nakasone T, Hanashiro K, Nakamura M, Sunakawa H, Kosugi T. Mast cell-derived VEGF enhances the passage of IgE FE-3 through the rat aortic endothelial cell monolayer. Int Arch Allergy Immunol 2002; 129: 76-85.
[16] Suarez S, Ballmer-Hofer K. VEGF transiently disrupts gap junctional communication in endothelial cells. J Cell Sci 2001; 114: 1229-35.

[17] Dundar E, Oner U, Peker BC, Metintas M, Isiksoy S, Ak G. The significance and relationship between mast cells and tumour angiogenesis in nonsmall cell lung carcinoma. J Int Med Res 2008; 36: 88-95.

[18] Sawatsubashi M, Yamada T, Fukushima N, Mizokami H, Tokunaga O, Shin T. Association of vascular endothelial growth factor and mast cells with angiogenesis in laryngeal squamous cell carcinoma. Virchows Arch 2000; 436: 243-8.

[19] Tuna B, Yorukoglu K, Unlu M, Mungan MU, Kirkali Z. Association of mast cells with microvessel density in renal cell carcinomas. Eur Urol 2006; 50: 530-4.

[20] Ribatti D, Finato N, Crivellato E, et al. Angiogenesis and mast cells in human breast cancer sentinel lymph nodes with and without micrometastases. Histopathology 2007; 51: 837-42.

[21] Crivellato E, Nico B, Ribatti D. Mast cells and tumour angiogenesis: new insight from experimental carcinogenesis. Cancer Lett 2008; 269: 1-6.

[22] Ribatti D, Ennas MG, Vacca A, et al. Tumor vascularity and tryptase positive mast cells correlate with a poor prognosis in melanoma. Eur J Clin Invest 2003; 33: 420-5.

[23] Dvorak AM. Mast cell-derived mediators of enhanced microvascular permeability, vascular permeability factor/vascular endothelial growth factor, histamine, and serotonin, cause leakage of macromolecules through a new endothelial cell permeability organelle, the vesiculo-vacuolar organelle. Chem Immunol Allergy 2005; 85: 185-204.

[24] Broide DH. Immunologic and Inflammatory mechanisms that drive asthma progression to remodeling. J Allergy Clin Immunol 2008; 121: 560-70.

[25] Matsuura T, Takahashi K, Nakayama K, et al. Increased expression of vascular endothelial growth factor in placentas of p57 kip2 null embryos. FEBS Lett 532 (2002) 283-8.

[26] Lomo J, Blomhoff HK, Beiske K, Stokke T, Smeland EB. TGF- $\beta 1$ and cyclic AMP promote apoptosis in resting human B lymphocytes. J Immunol 1995; 154: 1634-43.

[27] Mekori YA, Oh CK, Metcalfe D. IL-3-dependent murine mast cells undergo apoptosis on removal of IL-3. J Immunol 1993. 151:377584.

[28] Fruttinger M. VEGF gene regulation. In: Ruhrberg C, Ed. VEGF in Development, Austin: Landes Bioscience and Springer Science+Business Media 2008; pp. 30-9.

[29] Pages G, Berra E, Milanini J, Levy A, Pouyssegur J. Stressactivated protein kinases (JNK and p38/HOG) are essential for vascular endothelial growth factor mRNA stability. J Biol Chem 2000; 275: 26484-91.

[30] Peifer C, Wagner G, Laufer S. New approaches to the treatment of inflammatory disorders: small molecule inhibitors of p38 MAP kinase. Curr Top Med Chem 2006; 6:113-49.

[31] Gomez G, Ramirez CD, Rivera J, et al. TGF-beta 1 inhibits mast cell Fc epsilon RI expression. J Immunol 2005; 174: 5987-93.

[32] Toyota N, Hashimoto Y, Matsuo S, Iizuka H. Transforming growth factor beta 1 inhibits IL-3- and IL-4-dependent mouse connective tissue-type mast cell proliferation. Arch Dermatol Res 1995; 287: 198-201.

[33] Broide DH, Wasermann SI, Alvaro-Gracia J, Zvaifler NJ, Firestein GS. Transforming growth factor -betal selectively inhibits IL-3 dependent mast cell proliferation without affecting mast cell function or differentiation. J Immunol 1989; 143: 1591-7.

[34] Rumsaeng V, Vliagoftis H, Oh CK, Metcalfe DD. Lymphotactin gene expression in mast cells following FceRI Receptor Aggregation. Modulation by TGF- $\beta$, IL-4, Dexametahasone and Cyclosporin A. J Immunol 1997; 158: 1353-60.

[35] Sanchez-Mejia RO, Lam BK, Arm JP. Matrix-associated transforming growth factor $\beta 1$ primes mouse bone marrow derived mast cells for increased high affinity Fc receptor for immunoglobulin Edependent eicosanoid biosynthesis. Am J Respir Cell Mol Biol 2000; 22: 557-65.

[36] Cha C, Mulkeen AL, Yoo PS, et al. Post-transcriptional regulation of VEGF: potential for novel therapies. J Am Coll Surg 2006; 203: S87-S93.

[37] Kawakami T, Kitamura J. Mast cell survival and activation by IgE in the absence of antigen: a consideration of the biological mechanisms and relevance. J Immunol 2005; 175: 4167-73. 
[38] Dibrov A, Kashour T, Amara FM. The role of transforming growth factor beta signaling in messenger RNA stability. Growth Factors 2006; 24: 1-11.

[39] Brennan CM, Steitz JA. HuR and mRNA stability. Cell Mol Life Sci 2001; 58: 266-77.

[40] Coles LS, Bartley MA, Bert A, et al. A multiprotein complex containing cold shock domain (Y-box) and polypyrimidine tract binding proteins forms on the vascular endothelial growth factor mRNA. Potential role in mRNA stabilization. Eur J Biochem 2004; 271: 648-60.

[41] Katsanou V, Ppadaki O, Millatos S, et al. HuR as a negative posttranscritpional modulator in inflammation. Mol Cell 2005; 19: 77789.

[42] Dvorak AM. Piecemal degranulation of basophils and mast cells is affected by vesicular transport of stored secretory granule contents. Chem Immunol Allergy 2005; 85: 135-84.

[43] Kesherwani V, Sodhi A. Quantitative role of p42 and p38 in the production and regulation of cytokines TNF- $\alpha$, IL1- $\beta$ and IL-12 by murine macrophages in vitro by concanavalin A. Cytokine 2007; 37: $62-70$.

[44] Zarubin T, Han J. Activation and signaling of the p38 MAP kinase pathway. Cell Res 2005; 15: 11-8.

[45] Mahtani KR, Brook M, Dean JLE, Sully G, Saklatvala J, Clark AR. Mitogen-Activated Protein kinase p38 controls the expression and posttranslational modification of tristetraprolin, a regulator of tumor necrosis factor alpha mRNA stability. Mol Cell Biol 2001; 21: 6461-9.

[46] Pascual RM, Peters SP. Airway remodeling contributes to the progressive loss of lung function in asthma: an overview. J Allergy Clin Immunol 2005; 116: 477-86.
[47] Flood-Page P, Menzies-Gow A, Phipps S, et al. Anti IL-5 treatment reduces deposition of ECM proteins in the bronchial subepithelial basement membrane of mild atopic athmatics. J Clin Invest 2003; 112: 1029-36.

[48] Zanni A, Chetta A, Saetta M, et al. Chymase positive mast cells play a role in the vascular component of airway remodeling in asthma. J Allergy Clin Immunol 2007; 120: 329-33.

[49] Chetta A, Zanini A, Foresi A, et al. Vascular endothelial growth factor up regulation and bronchial wall remodelling in asthma. Clin Exp Allergy 2005; 35: 1437-42.

[50] Wynn A. Common and unique mechanisms regulate fibrosis in various fibroproliferative diseases. J Clin Invest 2007; 117: 524-29.

[51] Leung SY, Niimi A, Noble A, et al. Effect of transforming growth factor beta receptor I kinase inhibitor 2, 4-disubstituted pteridine (SD-208) in chronic allergic airway inflammation and remodeling. J Pharmacol Exp Ther 2006; 319: 586-94.

[52] Wright SH, Brown J, Knight PA, Thorton EM, Kilshaw PJ, Miller HR. Transforming growth factor-beta1 mediates coexpression of the integrin subunit alpha $\mathrm{E}$ and the chymase mouse mast cell protease 1 during the early differentiation of bone marrow-derived mucosal mast cell homologues. Clin Exp Allergy 2002; 32: 315-24.

[53] Wrzesinski SH, Wan YY, Flavell RA. Transforming growth factor beta and the immune response: implications for anticancer therapy. Clin Cancer Res 2007; 13: 5262-70.

[54] Gordon JR, Zhang X, Stevenson D, Cosford K. Thrombin induces IL- 6 but not TNF- $\alpha$ secretion by mouse mast cells: threshold-level thrombin receptor and very low level of FceRI signaling synergistically enhance IL-6 secretion. Cell Immunol 2000; 205: 128-35.

Received: October 24, 2008

Revised: March 16, 2009

Accepted: March 18, 2009

(c) Benitez-Garrido et al.; Licensee Bentham Open.

This is an open access article licensed under the terms of the Creative Commons Attribution Non-Commercial License (http://creativecommons.org/licenses/by-nc/3.0/) which permits unrestricted, non-commercial use, distribution and reproduction in any medium, provided the work is properly cited. 